\title{
Quali-quantitative characterization of biogas with the temporal behavior of organic load on wastewater treatment plant with upflow anaerobic sludge blanket reactors through measurement in full-scale systems
}

Caracterização quali-quantitativa do biogás e suas relações com o comportamento temporal da carga orgânica em reatores anaeróbios de fluxo ascendente, em escala plena, no tratamento do esgoto sanitário, empregando equipamentos de medição online

Orlando Antonio Duarte Hernandez ${ }^{1}\left(\mathbb{D}\right.$, Ana Caroline Paula $^{1}\left(\mathbb{B}\right.$, Gustavo Rafael Collere Possetti $^{2}$ (D), Mauricio Pereira Cantão ${ }^{1}$ (D), Miguel Mansur Aisse ${ }^{1}$ (1)

\section{A B S T R A C T}

This study aims to present the time behavior of wastewater flow parameters, organic matter, biogas flow, biogas composition, and its relations, measured through online sensors, in a municipal wastewater treatment plant (WWTP) operating full-scale upflow anaerobic sludge blanket (UASB) reactors, installed in the south of Brazil. WWTP has online measurement devices to evaluate some physicochemical variables of the sewage and the biogas. The COD analyzer (UVVis probe), ultrasonic flow meter, biogas flow meter, and biogas composition analyzer were the equipment used. The monitoring occurred for two time periods each of $72 \mathrm{~h}$ and one time period for $48 \mathrm{~h}$ in the year 2018. Data were checked with descriptive statistics, data independence was checked through the autocorrelation BoxLjung test, normality behavior was checked with several tests (ShapiroWilk, Kolmogorov-Smirnov, Lilliefors, Anderson-Darling, D'Agostino K², and Chen-Shapiro), and Spearman's correlation coefficient was used to evaluate the correlations among the parameters. The mean sewage

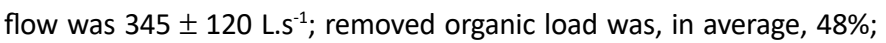
biogas quality values were $82.32 \% \pm 3.62 \% \mathrm{v} / \mathrm{v}\left(\mathrm{CH}_{4}\right), 2.66 \% \pm 1.19 \%$ $\mathrm{v} / \mathrm{v}\left(\mathrm{CO}_{2}\right)$, and $3453 \pm 1268 \mathrm{ppm}\left(\mathrm{H}_{2} \mathrm{~S}\right)$; and the production per capita

\section{R E S U M 0}

O trabalho teve como objetivo a caracterização qualiquantitativa do biogás e suas relações com o comportamento temporal da carga orgânica em reatores anaeróbios de fluxo ascendente (UASB), em escala plena, no tratamento do esgoto sanitário, empregando equipamentos de medição online. O trabalho foi conduzido em uma estação de tratamento de esgotos (ETE) instalada no Sul do Brasil. A ETE possui dispositivos de medição online para avaliar algumas variáveis físicoquímicas do esgoto e do biogás. Os equipamentos utilizados foram o analisador Demanda Química de Oxigênio (DQO) [sonda ultravioleta visível (UV-Vis)], medidor ultrassônico, medidor de biogás e analisador de composição de biogás. O monitoramento ocorreu por dois períodos de 72 horas cada e um período de 48 horas, no ano de 2018 . Os dados foram analisados com estatística descritiva, a independência dos dados foi averiguada por meio do teste de correlação Box-Ljung, a normalidade foi verificada pelos testes Shapiro-Wilk, KolmogorovSmirnov, Lilliefors, Anderson-Darling, D’Agostino K2 e Chen-Shapiro, e foi usado o método de Spearman para avaliar as correlações entre os parâmetros. A vazão média de esgoto foi $345 \pm 120 \mathrm{Ls}^{-1}$. A carga orgânica removida foi, em média, $48 \%$. Os valores de qualidade do

\footnotetext{
${ }^{1}$ Universidade Federal do Paraná - Curitiba, (PR), Brazil.

${ }^{2}$ Companhia de Saneamento do Paraná - Curitiba (PR), Brazil.

Correspondence address: Orlando Antonio Duarte Hernandez - Graduate Program in Water Resources and Environmental Engineering, Department of Hydraulics and Sanitation, Universidade Federal do Paraná - PO Box 19011 - Jardim das Américas - CEP: 81531 -990 - Curitiba (PR), Brazil. E-mail: oranduher1@gmail.com

Conflicts of interest: the authors declare that there are no conflicts of interest.

Funding: Brazil-Germany Project on Biogas (PROBIOGÁS), SANEPAR, UFPR, and INCT ETEs Sustentáveis (Brazilian National Science and Technology Institute for Sustainable WWTPs), Organization of American States (OAS), through cooperation with Brazilian Coordination for the Improvement of Higher Education Personnel - CAPES/UFPR.
}

Received on: 02/21/2021. Accepted on: 08/27/2021.

https://doi.org/10.5327/Z217694781059

This is an open access article distributed under the terms of the Creative Commons license. 
obtained was $4.51 \pm 1.65 \mathrm{NL} \cdot \mathrm{hab}^{-1} \cdot \mathrm{d}^{-1}$. It was estimated an electric power generation of $3118.6 \mathrm{kWh} . \mathrm{d}^{-1}$, which is equivalent to an installed power of $130 \mathrm{KW}$. The behavior of removed organic load and biogas flow $\left(\mathrm{Nm}^{3} \cdot \mathrm{h}^{-1}\right)$, produced in the treatment plant, showed variable, periodic, and nonstationary time behavior.

Keywords: biogas composition; biogas flow; chemical oxygen demand probe; sewage; ultrasonic flowmeter. biogás foram, para o metano ( $\mathrm{CH} 4), 82,32 \% \pm 3,62 \% \mathrm{v} / \mathrm{v}$ (percentagem volume-volume), para o dióxido de carbono (CO2) 2,66\% $\pm 1,19 \%$ v/v e para o sulfeto de hidrogênio (H2S) $3453 \pm 1268$ ppm. A produção de biogás per capita obtida foi $4,51 \pm 1,65 \mathrm{NL} \cdot \mathrm{hab}^{-1} \cdot \mathrm{d}^{-1}$. Foi estimada uma produção de energia eléctrica de $3.118,6 \mathrm{kWh} / \mathrm{d}$, o que é equivalente a uma potência instalada de $130 \mathrm{KW}$. O comportamento da carga orgânica removida e da vazão de biogás $\left(\mathrm{Nm} 3 . \mathrm{h}^{-1}\right)$ produzida na estação de tratamento, apresentaram um comportamento temporal variável, periódico e não estacionário.

Palavras-chave: composição biogás; esgoto; medidor ultrassônico; sonda demanda química de oxigênio; medidor ultrassônico; vazão biogás.

\section{Introduction}

The treatment of sewage in warm regions, such as South America and Caribe, generally occurs via anaerobic technologies, such as upflow anaerobic sludge blanket (UASB) reactors. Von Sperling and Oliveira (2009), Noyola et al. (2012), Chernicharo et al. (2015), and Mainardis et al. (2020) recognized the great advantages of UASB, since it allows the reduction of the costs of implementation, operation, and maintenance of wastewater treatment plants (WWTP); besides, it requires a low initial investment.

UASB reactors are well known for their efficiency on removal of organic matter and solids, low energy demand, and without adding chemicals. The structure of these reactors basically consists of a tank with a bottom layer of biological sludge and a settler and gas deflector on the top container. With the proper operation, a tendency of separation of solid, liquid, and gas phases occurs (Lettinga et al., 1983; Chernicharo et al., 1999). For these authors, among the main parameters related to the design of UASB reactors, hydraulic volumetric rate (HVR), hydraulic retention time (HRT), volumetric organic loading rate (Lv), and upflow velocity should be accounted.

Many studies have been conducted expressing or comparing the mean volumetric organic loading to the efficiencies of UASB reactors in the treatment of sewage. In this regard, volumetric organic loading is recommended to be between 2.5 and $3.5 \mathrm{~kg}$ COD. $\mathrm{m}^{3} \cdot \mathrm{d}^{-1}$ (Chernicharo et al., 1999; von Sperling and Chernicharo, 2005; Chernicharo et al., 2015). Previous studies from Lettinga et al. (1983) reported lower loads, similar to Aisse et al. (2002), presenting values of $1.80 \mathrm{~kg}$ COD. $\mathrm{m}^{-3} \cdot \mathrm{d}^{-1}$ for the hydraulic retention time of $8 \mathrm{~h}$. Aisse et al. (2002) mentioned the COD of $(151 \pm 64) \mathrm{mg} . \mathrm{L}^{-1}$ in the effluent of a UASB reactor treating urban wastewater. Considering the influent COD of $(453 \pm 147) \mathrm{mg} . \mathrm{L}^{-1}$, the authors obtained the COD efficiency removal of $67 \%$.

The gas phase, inherent to sewage treatment in UASB reactors, represents a great advantage, especially regarding biogas production with elevated methane content. Biogas in UASB reactors, treating municipal and domestic wastewater, presents its composition as follows: methane (70-80\%), nitrogen (10-25\%), carbon dioxide (5-10\%), and $\mathrm{H}_{2} \mathrm{~S}$ (1,000-2,000 ppm) (Noyola et al., 2006; Possetti et al., 2019). The proportion among these components depends on the type of biological treatment applied and on the substrate, which could be urban solid residues, domestic and municipal wastewater, sludge from municipal wastewater treatment, animal waste, among others (Venkatesch and Elmi, 2013; Mainardis et al., 2020).

Methane is associated with greenhouse gases, with $\mathrm{CH}_{4}$ global warming potential (GWP) being 28 times superior to $\mathrm{CO}_{2}$; thus, biogas combustion for energy production could avoid methane emissions and substitute fossil fuels, also reducing the $\mathrm{CO}_{2}$ eq tons released to the atmosphere (IPCC, 2014). Methane has a lower calorific value of $9.9 \mathrm{kWh} . \mathrm{Nm}^{-3}$, and its concentration defines the potential of recovering energy from the biogas; electric power production from biogas is an alternative with great expansion potential in Brazil. Biogas production rates, verified by Lobato et al. (2012), from 9.8 to $17.1 \mathrm{NL}^{\mathrm{h}} \mathrm{hab}^{-1} \cdot \mathrm{d}^{-1}$, and Cabral et al. (2017b), from 3 to $138 \mathrm{NL}\left(\mathrm{CH}_{4}\right) / \mathrm{kg}\left(\mathrm{COD}_{\text {remov }}\right)$, have been used by researchers and wastewater treatment plant managers.

Possetti et al. (2013), Waiss and Possetti (2015), and Cabral et al. (2017b) observed a direct correlation between the influent sewage flow and rainfall, with the consequent lowering of HRT and the production of biogas. For Possetti et al. (2018), the rainwater results in sewage dilution (increase of flow and lowering of COD concentration), significantly reducing the biogas production. Mota et al. (2019) studied the variations in the concentration of methane $\left(\mathrm{CH}_{4}\right)$, carbon dioxide $\left(\mathrm{CO}_{2}\right)$, and oxygen $\left(\mathrm{O}_{2}\right)$, during 24 -h periods, in a sanitary landfill, located in the Northeast Region of Brazil, with a predominantly hot tropical and mild semi-arid climate. The research area showed no significant seasonal variation, only periods with more or less rainfall. There were few changes in the climate of the semi-arid region of Northeastern Brazil during the year.

Pagliuso and Regattieri (2008) observed that the increasing municipal demand for electric power requires alternative sources, thus making it necessary a deep knowledge of the time behavior of biogas 
generated in anaerobic WWTP, which is still little used in Brazil. Electricity generation and consumption in the WWTP itself are options used worldwide. Some guidelines on distributed electricity from biogas are available in Rosenfeldt et al. (2015), Cabral et al. (2017a), Gomes et al. (2017), and Possetti et al. (2019).

New technologies rising in the market, especially those related to online and remote sensing, allow measurements in loco and in real time of biogas production in UASB reactors. Mota et al. (2019) recommended the development of further research, and estimating the potential biogas is particularly important to assess the feasibility of its exploitation for energy purposes.

In this context, this study aims to present the time behavior of wastewater flow parameters, organic matter, biogas flow, and biogas composition, measured with online sensors, in a municipal wastewater treatment plant operating with UASB reactors, in full scale.

\section{Materials and Methods}

This study took place in a medium-size WWTP, installed in the south of Brazil, with a design flow of $420 \mathrm{~L} . \mathrm{s}^{-1}$ of domestic sewage and serving approximately 180,000 inhabitants. The wastewater pretreatment occurs with two mechanized screens and one grit chamber. The biological treatment is done in six UASB reactors (secondary treatment), and post-treatment of anaerobic effluent occurs in aerated followed by sedimentation ponds. The biogas generated by the UASB reactors at the plant is destroyed in an enclosed flare.

The treatment plant has online measurement devices to evaluate the behavior of some physicochemical variables of the sewage and the biogas (Figure 1). The COD meter (probe) in the sewage, the sewage flowmeter, the biogas flowmeter, and the biogas quality analyzer were the equipment used in this research.

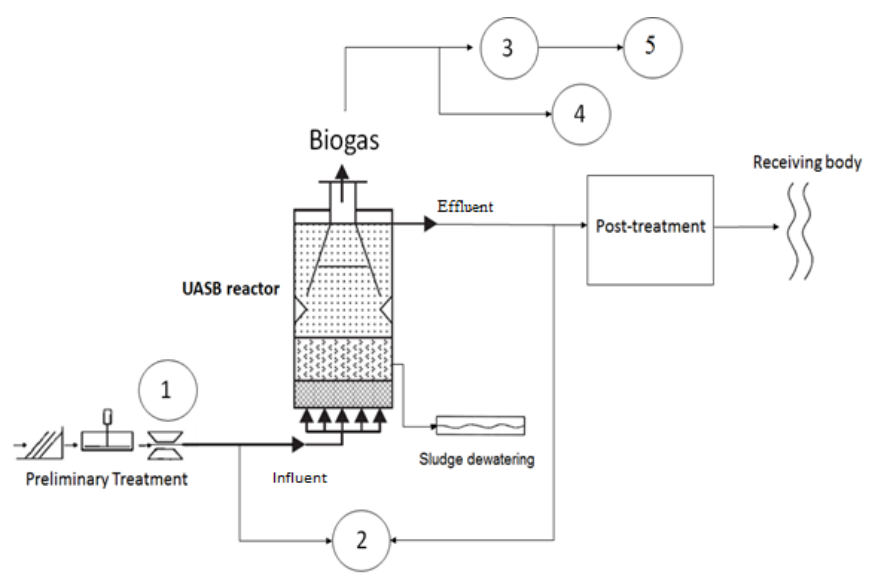

Figure 1 - Flowsheet of WWTP liquid phase and measurement equipment location. (1) Sewage flowmeter; (2) COD concentration meter; (3) biogas flowmeter; (4) biogas quality analyzer; and (5) biogas enclosed flare.

\section{Instrumentation}

The COD measurement system is composed of a spectrometer and a control unit; spectrometer probes work according to the principle of UV-Vis spectrometry. The system can determine concentrations between 100 and 3,250 $\mathrm{mg}(\mathrm{COD}) . \mathrm{L}^{-1}$. A detailed description of the probe can be found, e.g., in Langergraber et al. (2003) and Hernandez et al. (2018). The probe possesses an uncertainty of $1.8 \%$, for a probability coverage of $95.45 \%$ (Hernandez, 2019).

The treatment plant possesses an ultrasound flowmeter, with a resolution of $\pm 0.2 \%$, located over a Parshall flume in the inlet of the treatment plant. The equipment has an output with analog standard 4-20 mA, with an uncertainty of $\pm 0.001 \%$, for a probability coverage of 95.45\% (Hernandez, 2019).

The biogas flow was measured with a thermal dispersion transmitter, which is basically formed by two temperature probes (insert in the gas flow) and a heater. The energy required to maintain the sensor warm to a constant temperature is directly proportional to the gas velocity. Hence, correlations between energy and velocity are used to calculate the gas production. In this regard, the uncertainty of the equipment is $10.57 \%$ for a probability coverage of $95.45 \%$ (Hernandez, 2019).

The gas analyzer is a measurement system composed of a static unity and a portable measurement device, which receives biogas samples collected in the burning line. The biogas analyzer uses selective infrared probes to measure $\mathrm{CH}_{4}(0-100 \%) \mathrm{v} / \mathrm{v}$ and $\mathrm{CO}_{2}(0-100 \%) \mathrm{v} / \mathrm{v}$, and electrochemical probes to measure $\mathrm{O}_{2}(0-25 \%) \mathrm{v} / \mathrm{v}$ and $\mathrm{H}_{2} \mathrm{~S}(0-$ $5,000) \mathrm{ppm}$. Regarding the uncertainties, for the infrared probes, it is $\pm 1.5 \%$, whereas for the electrochemical probes, it was assumed to be $\pm 0.03 \%$ for a probability coverage of $95.45 \%$.

\section{Energy recovery from biogas}

The potential of energy generation via the use of the biogas produced in the WWTP was estimated through the following Equation 1 (Cabral et al., 2017a):

$\mathrm{EP}=\mathrm{Q}_{\mathrm{CH} 4} \cdot \mathrm{EC} \cdot \eta_{\text {electric }}$

Where:

$\mathrm{EP}=$ energy potential $\left(\mathrm{kWh} \cdot \mathrm{d}^{-1}\right)$;

$\mathrm{Q}_{\mathrm{CH} 4}=$ methane flow rate $\left(\mathrm{Nm}^{3} \cdot \mathrm{d}^{-1}\right)$;

$\mathrm{EC}=$ energetic content of methane (9.9 kWh. $\left.\mathrm{Nm}^{-3}\right)$;

$\eta_{\text {electric }}=$ electrical efficiency of a combined heat and power engine $(36 \%)$.

The power of the electric engine is calculated by dividing by $24 \mathrm{~h}$, in case of continuous use.

\section{Statistical evaluation criteria}

Temperature and operational data collected in the treatment plant were used, and precipitation data were registered with a pluviometer 
also located in the plant. In addition, the obtained values were transmitted to a database and subsequently treated in electronic datasheets for the elaboration of the descriptive statistics. The monitoring period occurred hourly for three consecutive days (72 h), in August and in September (samplings 1 and 2); in October, the data were collected for 48 consecutive hours (sampling 3), all in the year 2018. The Spearman's rank correlation coefficient $\left(r_{s}\right)$ was used to evaluate the monotonic correlations among the parameters for the significance level of 0.05 .

Rough data were checked with descriptive statistics and analyzed for outliers identification with the interquartile amplitude method. Data independence was checked through the autocorrelation Box-Ljung test (Ljung and Box, 1978), and the normality behavior was verified with the following normality tests: the Shapiro-Wilk test of normality (Shapiro and Wilk, 1965) and the Kolmogorov-Smirnov, Lilliefors, AndersonDarling, D’Agostino K2, and Chen-Shapiro tests (Adefisoye et al., 2016; Razali and Wah, 2011). If normal distribution and lack of autocorrelation are not to be rejected, for a 0.05 significance level, the $p$-values of the Shapiro-Wilk and Box-Ljung tests are higher than 0.05.

\section{Results and Discussion}

The climate of the South Region in Brazil, which is located below the Tropic of Capricorn in a temperate zone, is influenced by the system of disturbed circulation of the south, which produces the rains, mainly in the summer. In the evaluation period, the wastewater collection system was subjected to atmospheric precipitations of up to $38 \mathrm{~mm} /$ day. Regarding temperatures, the winter is cool and the summer is hot. The annual medium temperatures range from 14 to $22^{\circ} \mathrm{C}$, and in places with altitudes above $1,100 \mathrm{~m}$, it drops to approximately $10^{\circ} \mathrm{C}$. Some parts of the southern region also have an oceanic climate. Table 1 shows the meteorological data obtained at the treatment plant.

\section{Organic load}

In Figure 2, it is possible to observe the hourly behavior of the organic load, calculated from the relation of the hourly measurements of the ultrasound meter (flow) and spectrometer probe (COD concentration). The probe was used to measure COD in the influent and effluent of the reactor. The reported mean values for the three evaluated periods [sampling 1 (72 measurements), sampling 2 (72 measurements), and sampling 3 (48 measurements)] were $688 \pm 243 \mathrm{mg} . \mathrm{L}^{-1}$ for the influent and $358 \pm$ $116 \mathrm{mg} . \mathrm{L}^{-1}$ for the effluent. The mean sewage flow was $345 \pm 120{\mathrm{~L} . \mathrm{s}^{-1}}$, inferior to the design flow. Therefore, the organic influent load in the reactors was $19,782 \pm 9,949 \mathrm{~kg} \cdot \mathrm{d}^{-1}$ and the organic effluent load was $10,133 \pm 4,566 \mathrm{~kg} \cdot \mathrm{d}^{-1}$.

The UASB reactors presented the mean COD removal efficiency of $(47.25 \% \pm 12.03 \%)$, and the mean removed organic matter was 9,989 $\pm 5,980 \mathrm{~kg}(\mathrm{COD}) \cdot \mathrm{d}^{-1}$. Thus, the removal efficiencies were below the values reported by Aisse et al. (2002) and Oliveira and Von Sperling (2011). The removed organic matter was similar to the mean obtained by Bilotta and Ross (2016) for an equivalent treatment plant. The applied volumetric organic loading rate $(\mathrm{Lv})$ was $1.70 \pm 0.81 \mathrm{~kg}(\mathrm{COD}) \cdot \mathrm{m}^{3} \cdot \mathrm{d}^{-1}$, which is in accordance with the values reported by Lettinga et al. (1983) and Aisse et al. (2002).

The obtained HRT value of $9.58 \pm 2.29 \mathrm{~h}$ is coherent with the values reported by Oliveira and Von Sperling (2011), Chernicharo et al. (2015), and Metcalf and Eddy (2016), between 6 and 10 h, in terms of the mean flow, respecting the recommendations of the Brazilian Regulation NBR 12209 (ABNT, 2011).

\section{Characterization and biogas production}

Figure 3 presents the behavior of removed organic load $\left(\mathrm{kg} \cdot \mathrm{d}^{-1}\right)$ and biogas flow $\left(\mathrm{Nm}^{3} \cdot \mathrm{h}^{-1}\right)$ produced in the treatment plant. The curves present variable, periodic, and nonstationary time behavior, corroborating the biogas production values found by Possetti et al. (2013), Cabral et al. (2017b), and Possetti et al. (2019).

Figure $4 \mathrm{~A}$ presents the behavior of the hourly biogas concentration (quality) and the histograms of these measurements. The collected values were $82.32 \% \pm 3.62 \% \mathrm{v} / \mathrm{v}$ of methane $\left(\mathrm{CH}_{4}\right), 2.66 \% \pm 1.19 \% \mathrm{v} / \mathrm{v}$ of carbon dioxide $\left(\mathrm{CO}_{2}\right)$, and $3,453 \pm 1,268 \mathrm{ppm}$ of hydrogen sulfide $\left(\mathrm{H}_{2} \mathrm{~S}\right)$. In order to complete the $100 \% \mathrm{v} / \mathrm{v}$ in the biogas composition, the difference was attributed to nitrogen $\left(\mathrm{N}_{2}\right)(\sim 15 \%) \mathrm{v} / \mathrm{v}$, dissolved in the raw sewage, and removed in the gas phase of the UASB reactor (Noyola et al., 2006).

The presented results indicate that the control and the monitoring of the generated biogas characteristics should be performed continuously, since variation might occur. These variations could occur due to

Table 1 - Meteorological data at the treatment plant.

\begin{tabular}{|c|c|c|c|c|c|c|c|}
\hline \multirow{2}{*}{ Day } & \multirow{2}{*}{ Temperature ${ }^{\star}\left({ }^{\circ} \mathbf{C}\right)$} & \multirow{2}{*}{ Weather } & \multicolumn{5}{|c|}{ Pluviometry (mm) } \\
\hline & & & Day $(-1)^{\star \star}$ & Day (1) & Day (2) & Day (3) & Average (mm) \\
\hline $\begin{array}{l}\text { Sample Collection } 1 \\
\text { (August) }\end{array}$ & 17 & Dry/cloudy & 0 & 0 & 0 & 8 & 2 \\
\hline $\begin{array}{l}\text { Sample Collection } 2 \\
\text { (September) }\end{array}$ & 20.1 & Dry/rainy & 0 & 2 & 2 & 4 & 2 \\
\hline $\begin{array}{l}\text { Sample Collection } 3 \\
\text { (October) }\end{array}$ & 16 & Rain & 16 & 38 & 12 & 12 & 19.5 \\
\hline
\end{tabular}

${ }^{*}$ The temperature means of the period evaluated; ${ }^{* *}$ the precipitation 1 day before starting the evaluation. 


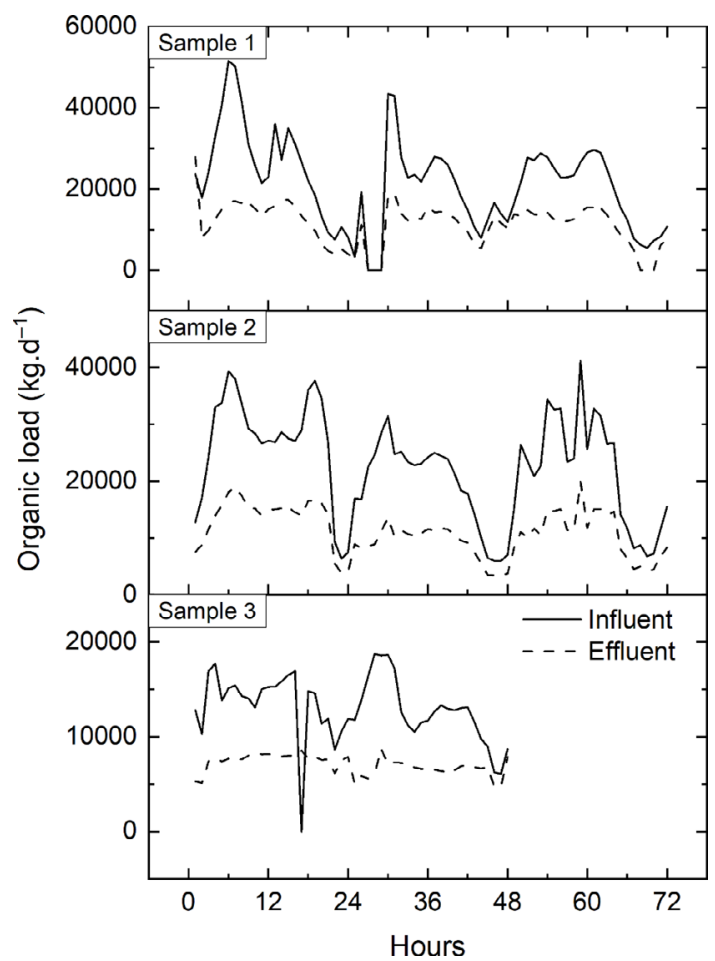

Figure 2 - Organic load at UASB reactors $\left[\mathrm{kg}(\mathrm{COD}) . \mathrm{d}^{-1}\right]$.

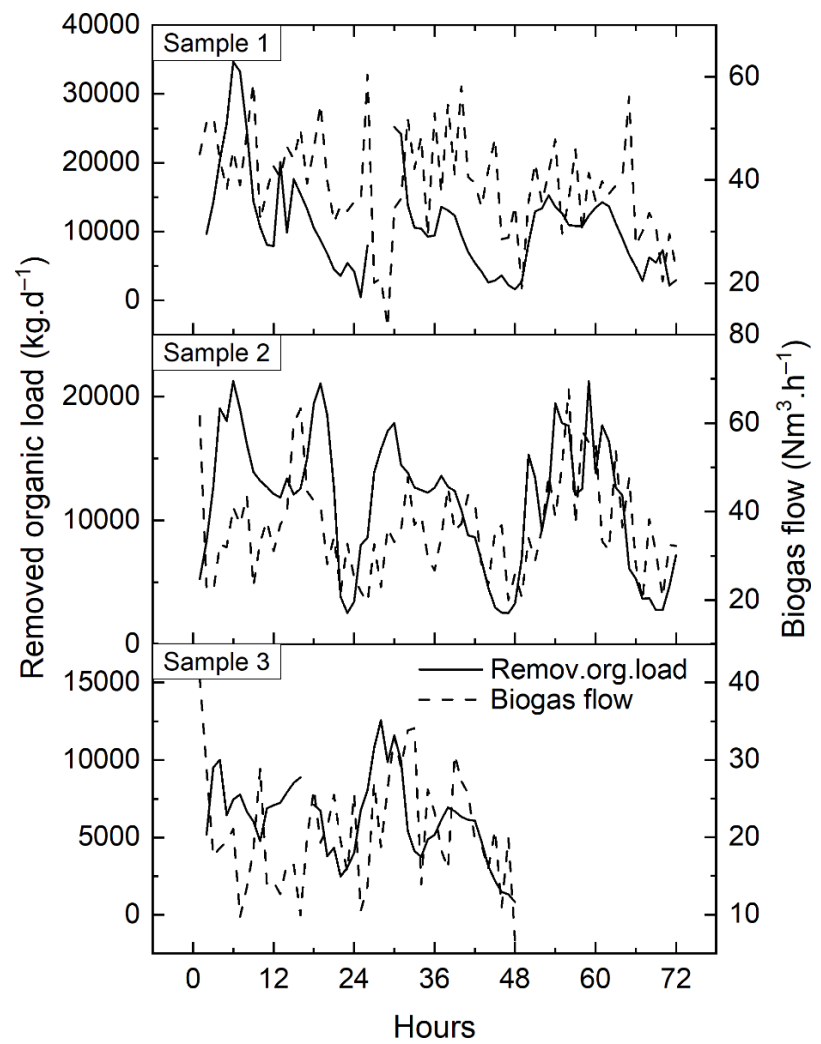

Figure 3 - Removed organic load curve $\left(\mathrm{kg}^{-\mathrm{d}^{-1}}\right)$ and biogas flow curve $\left(\mathrm{Nm}^{3} \cdot \mathrm{h}^{-1}\right)$ as function of time (h). climate, characteristics of the basin, and population that contributes to the treatment plant or occurrence of disturbances in the process of anaerobic digestion (WEF, 1994, 1998; Brasil, 2017).

Figure $4 \mathrm{~B}$ shows the histograms of biogas hourly concentration. Regarding $\mathrm{H}_{2} \mathrm{~S}$, it was possible to observe greater clusters between 1,700 and 3,700 ppm, highlighting the bimodal feature of the data. For samplings 1 and 2, values ranged mainly between 3,400 and 5,500 ppm, while for sampling 3 , the values were located primarily in the interval between 500 and 3,000 ppm (see Figure 4A). The multimodality generally occurs when the data are collected from more than one process or condition. It is believed that rainfall could be the explanation for such behavior. In the period of sampling 3 , the mean rainfall was $19.5 \mathrm{~mm} . \mathrm{d}^{-1}$, in comparison with samplings 1 and 2 , with a mean rainfall of $2 \mathrm{~mm} \cdot \mathrm{d}^{-1}$. The gas emission did not show a significant difference between the end of the rainy period and the end of the dry period (Pinheiro et al. 2019).

It is noteworthy that the minimum concentration of $\mathrm{H}_{2} \mathrm{~S}$ was $130 \mathrm{ppm}$, and the maximum was 5,457 ppm (Figure 4B). The obtained data could be interesting to adequate, for example, the chemical dosage in the systems for controlling odor, in anaerobic treatment reactors, or to increase the dosage in periods where a greater concentration of $\mathrm{H}_{2} \mathrm{~S}$ is expected. However, for the use of biogas to generate energy, gas treatment is required. For example, motor-generator groups typically demand concentrations of $\mathrm{H}_{2} \mathrm{~S}$ below $130 \mathrm{ppm}$ for proper functioning (Soreanu et al., 2011).

Carbon dioxide presented, as seen by Noyola et al. (2006), an asymmetry of the collected data distribution to the left, with the minimum concentrations of $0.7 \%$ and maximum concentrations of $6.2 \% \mathrm{v} / \mathrm{v}$. The histogram also indicates bimodal behavior.

Methane was within the maximum of $94.5 \%$ and the minimum of $76.6 \%$. It could be mentioned that in the greater data series, grouping is in the interval between 75 and $87.5 \%$. Moreover, it is evident that the lowest values occurred during sampling 3, rainy period, which is coherent with meteorological conditions (see Table 1) and the data by Possetti et al. (2013) and Cabral et al. (2017b).

The biogas flow showed a relative symmetric distribution, presenting higher frequency in the measurements when the equipment measured between 25 and $45 \mathrm{Nm}^{3} \cdot \mathrm{d}^{-1}$. Figure $4 \mathrm{~B}$ shows a normal distribution line for the biogas flow; visual inspection indicates possible normality for this parameter but not for the gas concentrations. Biogas flow and removed organic load were tested with the OriginPro ${ }^{\odot}$ software-based normality tests: Shapiro-Wilk, Chen-Shapiro, Anderson-Darling, Kolmogorov-Smirnov, Lilliefors, and D’Agostino $\mathrm{K}^{2}$ (omnibus). Each collected sample and the ensemble of all samples were tested, and the results are shown in Table 2.

Razali and Wah (2011) compared the power of the first four tests (Shapiro-Wilk, Anderson-Darling, Lilliefors, and KolmogorovSmirnov), verifying that they are in descending order ( $\mathrm{S}-\mathrm{W}$ being the most powerful and K-S the less one). Razali and Wah (2011) also showed that the maximum normality test power occurs for $\mathrm{N}>200$ for symmetric distributions and $\mathrm{N}>50$ for asymmetric distributions. 

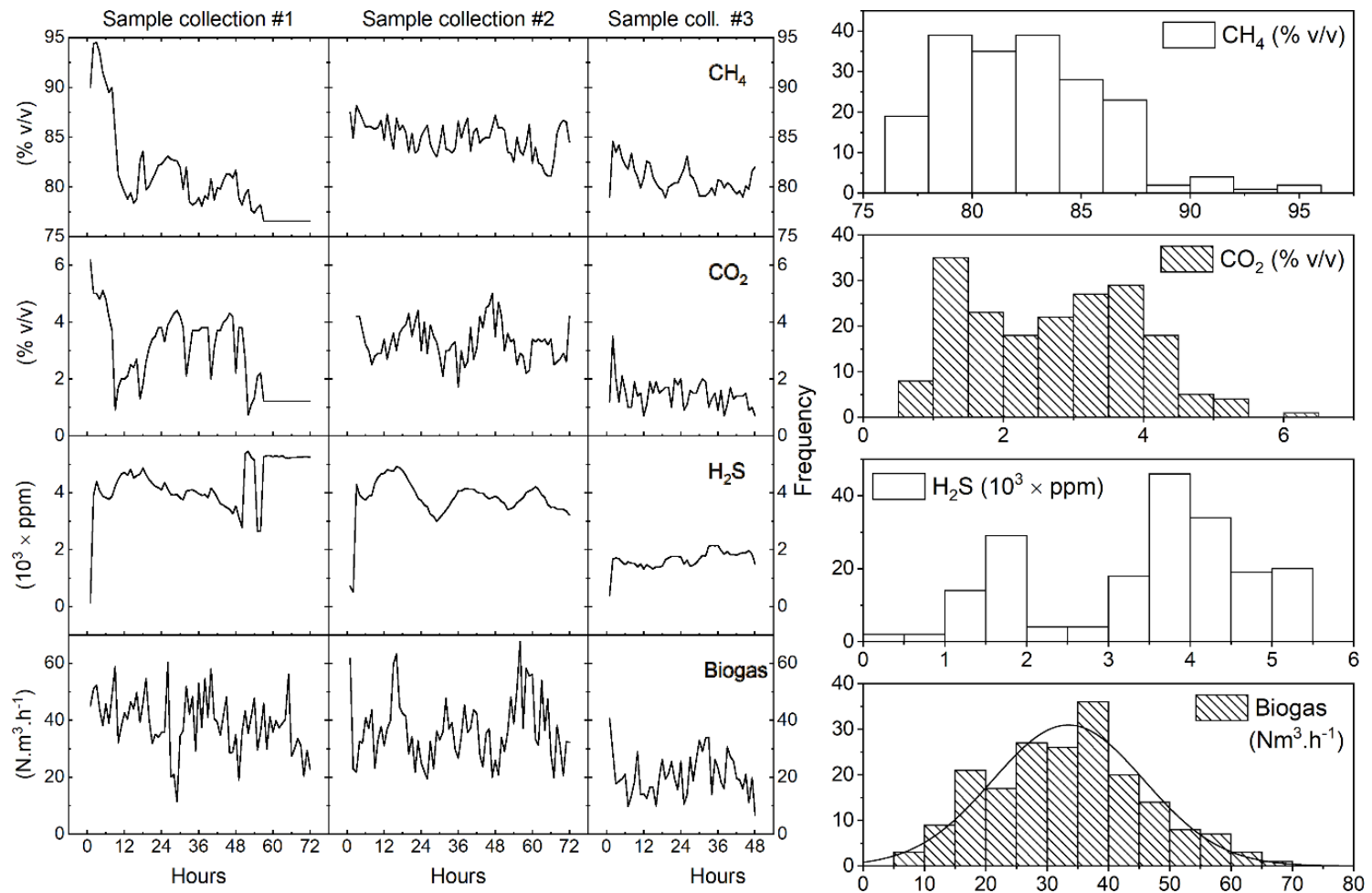

Figure 4 - Behavior of biogas hourly concentration (quality) and the histograms of these measurements. (A) Data distribution of the $\mathrm{H}_{2} \mathrm{~S}, \mathrm{CO}_{2}, \mathrm{CH}_{4}$ and biogas flow data for all periods evaluated and (B) behavior of $\mathrm{H}_{2} \mathrm{~S}, \mathrm{CO}_{2}, \mathrm{CH}_{4}$, and biogas flow of each period evaluated.

Table 2 - Normality test results for removed organic load and biogas flow.

\begin{tabular}{|l|c|c|c|c|c|c|c|c|c|}
\hline \multirow{2}{*}{ Normality tests } & \multicolumn{4}{|c|}{ Removed organic load } & \multicolumn{4}{c|}{ Biogas flow } \\
\cline { 2 - 9 } & Sample \#1 & Sample \#2 & Sample \#3 & All samples & Sample \#1 & Sample \#2 & Sample \#3 & All samples \\
\hline Shapiro-Wilk & Reject & Reject & Cannot reject & Reject & Cannot reject & Reject & Cannot reject & Cannot reject \\
\hline Anderson-Darling & Reject & Reject & Cannot reject & Reject & Cannot reject & Reject & Cannot reject & Cannot reject \\
\hline Lilliefors & Reject & Reject & Cannot reject & Reject & Cannot reject & Reject & Reject & Cannot reject \\
\hline Kolmogorov-Smirnov & Cannot reject & Reject & Cannot reject & Cannot reject & Cannot reject & Cannot reject & Cannot reject & Cannot reject \\
\hline D’Agostino Omnibus & Reject & Reject & Cannot reject & Reject & Cannot reject & Reject & Cannot reject & Cannot reject \\
\hline Chen-Shapiro & Reject & Reject & Cannot reject & Reject & Cannot reject & Reject & Cannot reject & Cannot reject \\
\hline
\end{tabular}

Table 2 demonstrates that the individual samples and the ensemble of all samples have different behavior. All the tests for the removed organic load sample \#3 indicate possible normal distribution, while samples \#1 and \#2 clearly are not normal. Removed organic load all-samples ensemble reproduces the average behavior of major data. Only biogas flow sample \#2 shows non-normal behavior.

Most normality tests show coherent results, the exceptions being Kolmogorov-Smirnov and Lilliefors, which is a modification of the
K-S test. Normality test results indicate a non-normality trend for removed organic load and normality trend for biogas flow.

The biogas flow, along with the biogas quality, could be of great help, for example, in the operation of a sludge thermal drying system or the possible implementation of a gasometer, for the storage of biogas generated in the treatment plant.

When comparing the removed organic matter with the flow parameters, $\mathrm{CH}_{4}$ percentage, $\mathrm{CO}_{2}$ percentage, and concentration of $\mathrm{H}_{2} \mathrm{~S}$, 
Table 3 - Matrix of Spearman's correlation coefficient $(r)$ between analyzed parameters*.

\begin{tabular}{|l|c|c|c|c|c|}
\hline & $\begin{array}{c}\text { Removed } \\
\text { organic load }\end{array}$ & $\begin{array}{c}\text { Biogas } \\
\text { flow }\end{array}$ & $\mathrm{CH}_{4}$ & $\mathrm{CO}_{2}$ & $\mathrm{H}_{2} \mathrm{~S}$ \\
\hline $\begin{array}{l}\text { Removed } \\
\text { organic } \\
\text { load }\end{array}$ & 1 & 0.43 & 0.36 & 0.29 & 0.32 \\
\hline Biogas flow & & 1 & 0.15 & 0.30 & 0.52 \\
\hline $\mathrm{CH}_{4}$ & & & 1 & 0.57 & -0.01 \\
\hline $\mathrm{CO}_{2}$ & & & & 1 & 0.25 \\
\hline $\mathrm{H}_{2} \mathrm{~S}$ & & & & & 1 \\
\hline
\end{tabular}

${ }^{\star} 0.05$ significance level.

it was observed that the organic load is positively correlated with the four parameters. The larger correlation coefficients were for removed organic matter versus biogas flow $\left(r_{s}=0.44\right)$ and $\mathrm{CH}_{4}$ percentage $\left(r_{\mathrm{s}}=0.34\right)$, respectively. Additionally, there is no direct influence between the percentage of $\mathrm{CH}_{4}$ and $\mathrm{H}_{2} \mathrm{~S}$ concentration, and a positive correlation of 0.52 was evidenced between biogas flow and $\mathrm{H}_{2} \mathrm{~S}$. The correlation coefficients obtained through the Spearman method are presented in Table 3. The correlation varies from negligible $\left(\left|r_{\mathrm{s}}\right| \sim 0\right)$ to moderate $\left(\left|r_{\mathrm{s}}\right| \sim 0.6\right)$.

\section{Specific biogas production} and potential of energy generation

Currently, the treatment plant attends a population of approximately 180,000 inhabitants. Since the average biogas production, in the evaluation period, was $36.46 \pm 12.35 \mathrm{Nm}^{3} \cdot \mathrm{h}^{-1}$, the biogas production rate per capita was calculated as $4.51 \pm 1.65 \mathrm{NL} \cdot \mathrm{hab}^{-1} \cdot \mathrm{d}^{-1}$. The biogas production rate with the removal rate was $80.4 \pm 29.68 \mathrm{NL} . \mathrm{kg}^{-1}$ (COD).

The unitary relations obtained in the studied treatment plant were close to the inferior limit reported by Lobato et al. (2012). When sampling 3 is studied separately, its biogas production rate per capita presents a considerable reduction, with the mean of $2.72 \pm 1.03 \mathrm{NL}$. $\mathrm{hab}^{-1} \cdot \mathrm{d}^{-1}$. The periods of intense rain resulted in the lowering of biogas production.

Power generation potential estimative based on the average biogas flow and methane content values found during the monitoring peri- od of WWTP was 3,118.6 kWh.d $\mathrm{d}^{-1}$, which is equivalent to an installed power of $130 \mathrm{KW}$. According to Rosenfeldt et al. (2015), Cabral et al. (2017a), Gomes et al. (2017), and Possetti et al. (2019), the decision on the best way to use biogas energy depends on the size and operational conditions of each WWTP and on on-site specific requirements, including social and environmental aspects.

\section{Conclusions}

The presented results revealed the behavior of different sewage parameters, such as organic load in the influent/effluent and removed organic matter in a wastewater treatment plant implemented, with UASB reactors operating in full scale, including biogas production, and adopting the time behavior in a full-scale approach. Mean hourly values were reported in the evaluation period for COD in the influent sewage, COD in the effluent sewage, sewage flow, biogas flow, and biogas composition (82.32\% of methane).

Visual inspection indicates normality for biogas flow, but not for the gas concentrations. Most of the applied normality tests showed coherent results, the exceptions being Kolmogorov-Smirnov and Lilliefors, which is a modification of the K-S test. Normality test results indicate a non-normality trend for removed organic load and a normality trend for biogas flow.

The organic load $\left[\mathrm{kg}(\mathrm{COD}) \cdot \mathrm{d}^{-1}\right]$ was inferior to design parameters, and the removed organic matter efficiency was, in average, $48 \%$. Both removed organic load and biogas flow $\left(\mathrm{Nm}^{3} \cdot \mathrm{h}^{-1}\right)$, produced in the treatment plant, showed variable, periodic, and nonstationary time behavior. The hourly removed organic matter has shown a positive moderate Spearman's rank correlation coefficient with biogas flow, $\mathrm{CH}_{4}$ percentage, $\mathrm{CO}_{2}$ percentage, and concentration of $\mathrm{H}_{2} \mathrm{~S}$. Also, it was verified that there are no direct correlations between biogas flow and the concentration of $\mathrm{H}_{2} \mathrm{~S}$.

The mean biogas production per capita obtained was 4.51 $\pm 1.65 \mathrm{NL} \cdot \mathrm{hab}^{-1} \cdot \mathrm{d}^{-1}$, a value inferior to that reported in the literature. The values of biogas composition $(82.32 \% \pm 3.62 \%) \mathrm{v} / \mathrm{v}\left(\mathrm{CH}_{4}\right)$ were in accordance with the values mentioned by Noyola et al. (2006), with $\mathrm{H}_{2} \mathrm{~S}$ resulting in the superior limit reported in the literature (between $1,700$ and $3,700 \mathrm{ppm})$. In the period of sampling 3 , the mean rainfall was $19.5 \mathrm{~mm} . \mathrm{d}^{-1}$, resulting in the reduction of organic load and biogas production. It was estimated an electric power generation of $3,118.6 \mathrm{kWh} . \mathrm{d}^{-1}$, which is equivalent to an installed power of $130 \mathrm{KW}$.

\section{Contribution of authors:}

Duarte Hernandez, O.A.: Conceptualization, Methodology, Validation, Formal analysis, Investigation, Resources, Writing - original draft; Paula, A.C.: Conceptualization, Methodology, Validation, Formal analysis, Investigation, Resources, Writing - original draft; Possetti, C.G.R.: Conceptualization, Methodology, Validation, Formal analysis, Investigation, Resources, Writing — original draft; Cantao, P.M.: Conceptualization, Methodology, Validation, Formal analysis, Investigation, Resources, Writing — original draft; Aisse, M.M.: Conceptualization, Methodology, Validation, Formal analysis, Investigation, Resources, Writing - original draft. 


\section{References}

Adefisoye, J.O.; Golam Kibria, B.M.; George, F., 2016. Performances of Several Univariate Tests of Normality: An Empirical Study. Journal of Biometrics \& Biostatistics, v. 7, (4), 322. https://doi.org/10.4172/2155-6180.1000322.

Aisse, M.M.; Lobato, M.B.; Jürgensen, D.; Além Sobrinho, P., 2002. Tratamento de efluentes anaeróbios com descarga de lodo aeróbio em reatores UASB (Treatment of Anaerobic Effluents with Discharge of Aerobic Sludge to the UASB Reactor). In: VII Taller e Simpósio Latino Americano sobre Digestion Anaerobia. Merida, Mexico.

Associação Brasileira de Normas Técnicas - ABNT, 2011. NBR 12209. Elaboração de projetos hidráulico-sanitários de estações de tratamento de esgotos sanitários. ABNT, Rio de Janeiro.

Bilotta, P.; Ross, B.Z.L., 2016. Estimativa de geração de energia e emissão evitada de gás de efeito estufa na recuperação de biogás produzido em estação de tratamento de esgotos. Revista Engenharia Sanitária e Ambiental, v. 21, (2), 275-282. https://doi.org/10.1590/S1413-41522016141477.

Brasil. 2017. Guia técnico de aproveitamento energético de biogás em estações de tratamento de esgoto (Technical guide on the use of biogas energy in wastewater treatment plants). 2a ed. Ministério das Cidades, Brasília, 183 pp.

Cabral, B.G.C., Chernicharo, C.A.L., Platzer, C.J., Barjenbruch, M., Belli Filho, P., 2017a. Evaluation of biogas production and energy recovery potential in 5 full-scale WWTPs with UASB reactors. Chemical Engineering and Chemical Process Technology, v. 3, (3), 1043.

Cabral, B.G.C.; Possetti G.R.; Platzer, C.J.; Barjenbruch, M.; Chernicharo, C.A.L., 2017b. Avaliação da produção de biogás em reatores UASB em escala plena tratando esgoto doméstico: correlações a partir de medições em tempo real. In: $29^{\circ}$ Congresso Brasileiro de Engenharia Sanitária e Ambiental.

Chernicharo, C.A.L.; van Haandel, A.; Aisse, M.M.; Cavalcanti, P., 1999. Reatores anaeróbios de manta de lodo. (Anaerobic Sludge Blanket Reactors). In: Campos, J.R. (Coord.). PROSAB. ABES, Rio de Janeiro, pp. 55-198.

Chernicharo, C.A.L.; van Lier, J.B.; Noyola, A.; Bressani Ribeiro, T., 2015. Anaerobic sewage treatment: state of the art, constraints and challenges. Reviews in Environmental Science and Bio/Technology, v. 14, 649-679. https:// doi.org/10.1007/s11157-015-9377-3.

Gomes, E.C.; Dias, I.A.; Ferreira, L.R.A.; Otto, R.B.; Moreira, H.C.; Possetti, G.R.C.; Wagner, L.G.; Junior, J.A.S.; Zeni, A.L., 2017. Guia técnico sobre geração distribuída de energia elétrica por biogás em ETEs/Probiogás. GIZ/ Ministério das Cidades, Brasília.

Hernandez, O.A.D., 2019. Avaliação de sistemas de medição para controle de processo em tempo real em uma estação de tratamento de esgoto sanitário que utiliza reatores UASB. Doctoral Thesis, Programa de Pós-Graduação em Engenharia de Recursos Hídricos e Ambiental, Setor de Tecnologia, Universidade Federal do Paraná, Curitiba. Retrieved 2021-09-29, from http:// www.prppg.ufpr.br/ppgerha/es/teses.

Hernandez, O.A.D.; Lisboa, A.M.; Cantão, M.P.; Possetti, G.R.C.; Aisse, M.M., 2018. Assessment of an in situ real time UV/Vis based spectrometry system for chemical oxygen demand measurement in a wastewater anaerobic treatment reactor. In: Matsumura-Tundisi, T.; Tundisi, J.G. (Eds.), Water Resources Management. Scienza, São Carlos, pp. 167-180.

Intergovernmental Panel on Climate Change - IPCC. 2014. Climate change: mitigation of climate change. Working Group III Contribution to the Fifth Assessment Report of the Intergovernmental Panel on Climate Change. Cambridge University Press, Cambridge.

Langergraber, G.; Fleischmann, N.; Hofstädter, F., 2003. A multivariate calibration procedure for UV/VIS spectrometric quantification of organic matter and nitrate in wastewater. Water Science \& Technology, v. 47, (2), $63-$ 71. https://doi.org/10.2166/wst.2003.0086.

Lettinga, G.; Roersma, R.; Grin P., 1983. Anaerobic treatment of raw domestic sewage at ambient temperatures using a granular bed UASB reactor. Biotechnology and Bioengineering, v. 25, (7), 1701-1723. https://doi. org/10.1002/bit.260250703.

Ljung, G.M.; Box, G.E.P., 1978. On a measure of lack of fit in time series models. Biometrika, v. 65, (2), 297-303. https://doi.org/10.2307/2335207.

Lobato, L.C.S.; Chernicharo, C.A.L.; Souza, C.L., 2012. Estimates of methane loss and energy recovery potential in anaerobic reactors treating domestic wastewater. Water Science \& Technology, v. 66, (12), 2745-2753. https://doi. org/10.2166/wst.2012.514.

Mainardis, M.; Buttazzoni, M.; Goi, D., 2020. Up-flow anaerobic sludge blanket (UASB) technology for energy recovery: a review on state-of-the-art and recent technological advances. Bioengineering, v. 7, (2), 43. https://dx.doi. org/10.3390\%2Fbioengineering7020043.

Metcalf, L.; Eddy, H.P., 2016. Wastewater engineering: treatment and resource recovery. $5^{\mathrm{a}}$ ed. AMGH, Porto Alegre.

Mota, F.; Monteiro, L.; Silva, W.; Borges, D., 2019. Climatic characteristics and hourly variations in biogas concentration in a sanitary landfill in northeast Brazil. Revista Brasileira de Ciências Ambientais (Online), (54), 1-12. https:// doi.org/10.5327/Z2176-94782190077.

Noyola, A.; Morgan-Sagastume, J.M.; Lopez-Hernandez, J.E., 2006. Treatment of biogas produced in anaerobic reactors for domestic wastewater: odor control and energy/resource recovery. Reviews in Environmental Science and Bio/Technology, (5), 93-114. https://doi.org/10.1007/s11157005-2754-6.

Noyola, A.; Padilla-Rivera, A.; Morgan-Sagastume, J.M.; Guereca, L.P.; Hernandez-Padilla, F., 2012. Typology of municipal wastewater treatment technologies in Latin America. Clean Soil Air Water, v. 40, (9), 926-932. https://doi.org/10.1002/clen.201100707.

Oliveira, S.C.; Von Sperling, M., 2011. Performance evaluation of different wastewater treatment technologies operating in a developing country. Journal of Water, Sanitation and Hygiene for Development, v. 1, (1), 37-56. https://doi. org/10.2166/washdev.2011.022.

Pagliuso, J.; Regattieri, C., 2008. Estudo do aproveitamento da energia do biogás proveniente da incineração do chorume para a geração de eletricidade. Revista Brasileira de Ciências Ambientais (Online), (10), 32-38. Retrieved 2021-05-15, from: http://www.rbciamb.com.br/index.php/Publicacoes_ RBCIAMB/article/view/428.

Pinheiro, L.; Cattanio, J. H.; Imbiriba, B.; Castellon, S.; Elesbão, S.; Ramos, J., 2019. Carbon dioxide and methane flux measurements at a large unsanitary dumping site in the amazon region. Revista Brasileira de Ciências Ambientais (Online), (54), 13-33. https://doi.org/10.5327/Z2176947820190021.

Possetti, G.R.C.; Jasinski, V.P.; Mesquita, N.C.; Kriguel, K.; Carneiro, C., 2013. Medições em tempo real do biogás produzido em reatores UASB alimentados com esgoto doméstico. In: $27^{\circ}$ Congresso Brasileiro de Engenharia Sanitária e Ambiental, Goiânia.

Possetti, G.R.C.; Rietow, J.C.; Cabral, C.B.G.; Moreira, H.C.; Platzer, C.; Ribeiro, T.B.; Chernicharo, C.A.L., 2019. Energy recovery from biogas in UASB reactors treating sewage. In: Chernicharo, C.A.L.; Ribeiro, T.B. (Eds.), Anaerobic reactors for sewage treatment: design, construction and operation. IWA Publishing, pp. 194-236. 
Possetti, G.R.C.; Rietow, J.C.; Costa, F.J.O.G.; Wagner, L.G.; Lobato, L.C.S.; Ribeiro, T.B.; Melo, D.F.; Reis, J.A.; Chernicharo, C.A.L., 2018. Contribuição para o aprimoramento de projeto, construção e operação de reatores UASB aplicados ao tratamento de esgoto sanitário - Parte 5: Biogás e emissões fugitivas de metano. Revista DAE, v. 66, (214), 73-89. https://doi.org/10.4322/ dae.2018.042.

Razali, N.M.; Wah, Y.B., 2011. Power comparisons of Shapiro-Wilk, Kolmogorov-Smirnov, Lilliefors and Anderson-Darling tests. Journal of Statistical Modeling and Analytics, v. 2, (1), 21-33.

Rosenfeldt, S.; Cabral, C.B.G.; Platzer, C.J.; Hoffmann, H.; Araujo, R.A., 2015. Avaliação da viabilidade econômica do aproveitamento energético do biogás por meio de motor-gerador em uma ETE. In: $28^{\circ}$ Congresso Brasileiro de Engenharia Sanitária e Ambiental.

Shapiro, S.S.; Wilk, M.B., 1965. An analysis of variance test for normality (complete samples). Biometrika, v. 52, (3-4), 591-611. https://doi. org/10.2307/2333709.

Soreanu, G.; Béland, M.; Falletta, P.; Edmonson, K.; Svoboda, L.; Al-Jamal, M.; Seto, P., 2011. Approaches concerning siloxane removal from biogas: a review. Canadian Biosystems Engineering, v. 53, 8.1-8.18.
Venkatesch, G.; Elmi, R.A., 2013. Economic-environmental analysis of handling biogas from sewage sludge digesters in WWTPs (wastewater treatment plants) for energy recovery: case study of Bekkelaget WWTP in Oslo (Norway). Energy, 58, 220-235. https://doi.org/10.1016/j.energy.2013.05.025.

Von Sperling, M.; Chernicharo, C.A.L., 2005. Biological wastewater treatment in warm climate regions. IWA Publishing, London, $1452 \mathrm{pp}$.

Von Sperling, M.; Oliveira, S.M.A.C., 2009. Comparative performance evaluation of full-scale anaerobic and aerobic wastewater treatment processes in Brazil. Water Science \& Technology, v. 59, (1), 15-22. https://doi. org/10.2166/wst.2009.841

Waiss, T.C.F.; Possetti, G.R.C., 2015. Influência de eventos de chuva na produção de biogás de reatores anaeróbios alimentados com esgoto doméstico. In: $28^{\circ}$ Congresso Brasileiro de Engenharia Sanitária e Ambiental, Rio de Janeiro.

Water Environment Federation - WEF. 1994. Preliminary treatment for wastewater facilities. Manual of Practice OM-2. WEF, Alexandria.

Water Environment Federation - WEF. 1998. Design of municipal wastewater treatment plants. Manual of Practice n. 8, ASCE Manual and Report on Engineering Practice, 76. WEF, Alexandria. 